\title{
CYTOTOXIC EFFECT OF FREEZE DRIED BOVINE CARTILAGE POWDER AND PLATELET RICH PLASMA (PRP) TO MESENCHYMAL STEM CELL (MSCs)
}

\author{
Dwikora Novembri Utomo ${ }^{1 *}$, Anthoni Yusbida ${ }^{2}$ \\ ${ }^{1}$ Senior Consultant of Orthopaedic and Traumatology Department, Faculty of Medicine, \\ Universitas Airlangga, Dr Soetomo General Hospital, Surabaya \\ ${ }^{2}$ Resident of Orthopaedic and Traumatology Department, Faculty of Medicine, Universitas \\ Airlangga, Dr Soetomo General Hospital, Surabaya \\ *Correspondence: Dwikora Novembri Utomo, Senior Consultant of Orthopaedic and \\ Traumatology Department, Faculty of Medicine, Universitas Airlangga, Jl. Mayjen Prof. Dr. \\ Moestopo 6-8, Surabaya \\ E-mail : dwikora_utomo@yahoo.com
}

\begin{abstract}
ABSTRAK
Perbaikan tulang rawan adalah masalah klinis yang menantang karena kerusakan merupakan kondisi yang ireversibel. Banyak penelitian telah dilakukan dengan menggunakan beberapa jenis scaffold alami maupun sintetis. Upaya untuk memperbaiki tulang rawan artikular dengan menggunakan scaffold biasanya memiliki banyak masalah, kekurangan pada struktur fisik dan sifat mekanik yang diperlukan untuk memastikan keefektivan jangka panjang terhadap kerusakan tulang rawan. Selain itu, scaffold sering menyebabkan toksisitas terhadap inang. Oleh karena itu penelitian ini dilakukan secara in vitro untuk menguji efek toksisitas dari scaffold bubuk tulang rawan dan platelet rich plasma (PRP). Penelitian ini dilakukan dengan menggunakan rancangan penelitian eksperimental murni pada 4 kelompok stem cell hewan yang ditambahkan dengan scaffold tulang rawan kering yang diberi platelet rich plasma (PRP). Penelitian ini menggunakan post test only control group design. Hasilnya diproses dengan MTT assay dan spektrofotometer untuk menghitung stem cell yang masih hidup. Tidak ada perbedaan yang signifikan dalam jumlah makrofag antara kelompok kontrol dan scaffold tulang rawan kering beku yang ditambahkan PRP $(\mathrm{p}=0,128)$. Dengan hasil ini pada jumlah makrofag antara kelompok kontrol dan scaffold tulang rawan kering beku yang ditambahkan PRP, dapat disimpulkan bahwa biomaterial ini memiliki biokompatibilitas.
\end{abstract}

Kata kunci : tulang rawan sapi beku kering, scaffold, platelet rich plasma, makrofag

\begin{abstract}
Cartilage repair is a challenging clinical problem because the damage is an irreversible condition. Many studies had been performed using several kinds of natural or synthetic scaffold. Attempts to repair articular cartilage using scaffold usually found many problems, lacks the physical structure and mechanical properties necessary to ensure long-term efficacy to cartilage defect. Furthermore, scaffold frequently cause toxicity to the host. Therefore, this study was performed in vitro to test the toxicity effect of scaffold freeze dried bovine cartilage powder and platelets Rich Plasma (PRP). This research was conducted using pure experimental research design in 4 groups of animal stem cells which being added with scaffold freeze dried bovine cartilage scaffold provided with platelet rich plasma. This study using posttest only control group design. The result being processed with MTT assay and spectrophotometer for counting the viable stem cells. There was no significant difference in the amount of macrophage between control and the freeze dried bovine cartilage scaffold provided with PRP $(\mathrm{p}=0,128)$. With this result in the number of macrophages between the control with freeze dried bovine cartilage scaffold provided PRP, it can be concluded that these biomaterials have biocompatibility.
\end{abstract}

Keywords : freeze dried bovine cartilage, scaffold, platelet rich plasma, macrophage 


\section{PENDAHULUAN}

Dari banyaknya cedera pada tulang dan sendi pada kecelakaan, kerusakan tulang rawan sendi masih merupakan masalah utama karena sering menimbulkan keluhan yang berkepanjangan dari penderita.

Hal tersebut sangat merugikan, karena berpengaruh signifikan terhadap menurunnya tingkat produktifitas akibat tingkat kesakitan penderita. Kerusakan tulang rawan sendi memerlukan pembiayaan yang tinggi baik untuk pembelian obat-obatan dan operasi. ${ }^{1}$ Salah satu perkembangan yang terbaru di bidang pengobatan tulang rawan sendi adalah pengobatan dengan teknik cartilage tissue engineering. Metode ini merupakan terapi kerusakan tulang rawan sendi dengan teknik yang berbasis sel, growth factor dan scaffold. Sel yang digunakan adalah kondrosit atau mesenchymal stem cells. Pada perkembangan terakhir sel yang sering digunakan adalah bone marrow mesenchymal stem cells. ${ }^{2}$

\section{Mesenchymal stem cells (MSCs)} adalah sel multipoten yang dapat berdeferensiasi ke dalam beberapa sel selama proses penyembuhan cedera jaringan. MSCs dapat berdeferensiasi menjadi cartilage pembentuk cartilage sendi, collagen, osteoblas. Sel itu secara bersama-sama mempunyai kemampuan untuk meregenerasi kerusakan jaringan yang disebabkan oleh trauma, perubahan degenerasi termasuk osteoarthritis. Regenerasi cartilage sendi dengan metode mesenchymal stem cells (MSCs) paling banyak digunakan saat ini karena potensinya yang dapat memperbaiki kerusakan jaringan secara signifikan. ${ }^{3}$ Sejumlah material scaffold baik alami maupun sintesis telah ditest secara in vitro dan in vivo dalam penelitian. Scaffold yang ideal mempunyai sifat biokompatibilitas untuk dapat mencegah reaksi radang dari sel-sel host, bentuk yang tiga dimensi untuk proliferasi dan diferensiasi sel, dan porositas yang cukup untuk migrasi sel dan difusi molekul, nutrisi dan oksigen. Matriks dari material tersebut juga harus dapat memfasilitasi implantasi sel tersebut pada lesi dan bertahan di dalam implan. ${ }^{4}$

Berbagai jenis scaffold telah dikembangkan untuk terapi kerusakan tulang rawan sendi, tetapi masing-masing memiliki kelebihan dan kekurangan. Untuk mengisi defek atau rongga pada tulang rawan, scaffold yang konvesional kurang cocok dipakai karena relatif tidak larut dan menyatu dengan tulang rawan. Scaffold yang biasa digunakan sampai sekarang berbentuk tiga dimensi sehingga biasanya implantasinya kurang baik pada tulang rawan. ${ }^{4}$ 
Di Bank Jaringan RS Dr. Soetomo dikembangkan scaffold berbentuk powder yang dibuat dari tulang rawan sapi dan diproses dengan freeze dried (beku kering). Untuk memudahkan implantasinya maka dikombinasi dengan platelet rich plasma (PRP Gel). Bubuk tulang rawan sapi ini larut pada PRP dan akan membentuk larutan yang berbentuk gel sehingga siap untuk diimplantasikan. PRP gel ini merupakan bahan yang banyak mengandung growth factor yang penting untuk regenerasi tulang rawan, proliferasi dan diferensiasi mesenchymal stem cells (MSCs).

Untuk penelitian lebih lanjut guna memanfaatkan bubuk tulang rawan sapi dan platelet rich plasma tersebut maka diperlukan suatu penelitian untuk mengetahui efeknya terhadap mesenchymal stem cells. Pada penelitian sebelumnya terbukti bahwa bubuk tulang rawan sapi tersebut dan platelet rich plasma biokompatibel terhadap jaringan. Diharapkan nantinya scaffold bubuk tulang rawan sapi ini dapat digunakan secara luas untuk pengobatan kerusakan tulang rawan sendi yang dikombinasi dengan mesenchymal stem cells.

\section{METODOLOGI PENELITIAN}

Penelitian ini adalah suatu penelitian experimental murni dengan rancangan post-test only control group design. Sampel penelitian dibagi menjadi empat kelompok, tiga kelompok mendapat perlakuan dan satu kelompok menjadi kontrol. Satu kelompok tidak dirikan perlakuan, satu kelompok mendapat platelet rich plasma (PRP) satu kelompok mendapat Freeze Dried Bovine Cartilage (FDBCP) dan satu lagi mendapatkan FDBCP dan PRP.

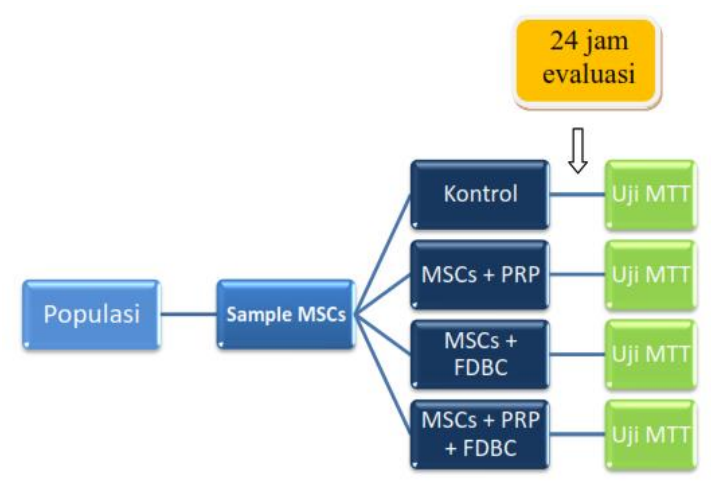

Gambar 1. Skema metodologi penelitian

\section{HASIL DAN PEMBAHASAN}

Penelitian eksperimental dimulai dengan pembuatan platelet rich plasma dan pengaktifan mesenchymal stem cell. Platelet rich plasma dan freeze dried bovine cartilage powder kemudian diuji toksisitasnya terhadap mesenchymal stem cell dengan MTT assay pada panjang gelombang $630 \mathrm{~nm}$. Data tentang pengaruh sitotoksik scaffold bubuk tulang rawan sapi dan platelet rich plasma secara kuantitatif dinilai dengan menggunakan uji viabilitas MTT assay terlihat pada tabel 1. 
http://journal.unair.ac.id/journal-of-orthopaedic-and-traumatology-surabaya-media-104.html

$\begin{array}{lll}\text { - Hasil perhitungan } & \text { jumlah } & \text { Perhitungan jumlah stem cell yang } \\ \text { mesenchymal stem cell } & & \text { didapatkan dengan ELISA reader } \\ & & \text { ditampilkan pada tabel } 1 \text { berikut. }\end{array}$

Tabel 1. Hasil Penelitian

\begin{tabular}{|c|c|c|c|}
\hline \multicolumn{3}{|c|}{ Hasil Pemeriksaan } & Statistic \\
\hline MSCs & $\begin{array}{l}\text { Mean } \\
\text { 95\% Confidence Interval for Mean } \\
5 \% \text { Trimmed Mean } \\
\text { Median } \\
\text { Std. Deviation }\end{array}$ & $\begin{array}{l}\text { Lower Bound } \\
\text { Upper Bound }\end{array}$ & $\begin{array}{l}, 71050 \\
, 60496 \\
, 81604 \\
, 70006 \\
, 68850 \\
, 166102\end{array}$ \\
\hline $\begin{array}{l}\text { MSCs + } \\
\text { PRP }\end{array}$ & $\begin{array}{l}\text { Mean } \\
95 \% \text { Confidence Interval for Mean } \\
5 \% \text { Trimmed Mean } \\
\text { Median } \\
\text { Std. Deviation }\end{array}$ & $\begin{array}{l}\text { Lower Bound } \\
\text { Upper Bound }\end{array}$ & $\begin{array}{l}1,17542 \\
1,03788 \\
1,31296 \\
1,16357 \\
1,15750 \\
216474\end{array}$ \\
\hline $\begin{array}{l}\text { MSCs + } \\
\text { FDBCP }\end{array}$ & $\begin{array}{l}\text { Mean } \\
95 \% \text { Confidence Interval for Mean } \\
5 \% \text { Trimmed Mean } \\
\text { Median } \\
\text { Std. Deviation }\end{array}$ & $\begin{array}{l}\text { Lower Bound } \\
\text { Upper Bound }\end{array}$ & $\begin{array}{l}, 67467 \\
, 59900 \\
, 75033 \\
, 67707 \\
, 68750 \\
, 119088\end{array}$ \\
\hline $\begin{array}{l}\text { MSCs + } \\
\text { PRP + } \\
\text { FDBCP }\end{array}$ & $\begin{array}{l}\text { Mean } \\
95 \% \text { Confidence Interval for Mean } \\
\text { 5\% Trimmed Mean } \\
\text { Median } \\
\text { Std. Deviation }\end{array}$ & $\begin{array}{l}\text { Lower Bound } \\
\text { Upper Bound }\end{array}$ & $\begin{array}{l}1,58317 \\
1,43867 \\
1,72766 \\
1,59641 \\
1,66650 \\
227418\end{array}$ \\
\hline
\end{tabular}

Dari data deskriptif diatas didapatkan bahwa kadar rata-rata MTT meningkat pada kelompok yang diberi PRP dan kelompok yang mendapat PRP+FDBCP. Sedangkan pada kelompok yang mendapat FDBCP terjadi penurunan kadar rata-rata MTT untuk mengetahui apakah peningkatan atau penurunan kadar rata-rata MTT ini signifikan, maka dilakukan uji statistik yaitu Uji ANOVA.

\section{- Uji Statistik ANOVA}

Karena diberikan empat perlakuan yang berbeda maka digunakan uji ANOVA. Untuk memakai uji ini maka data harus homogen dan varian data harus homogen.

\section{Uji homogenitas data}

Tabel 2. Homogenitas data penelitian

\begin{tabular}{|l|l|c|c|c|}
\hline \multirow{2}{*}{\multicolumn{2}{|c|}{ Perlakuan }} & \multicolumn{3}{|c|}{ Shapiro-Wilk } \\
\cline { 3 - 5 } & Statistic & Df & Sig. \\
\hline M & MSCS &, 887 & 12 &, 107 \\
\hline
\end{tabular}




\section{Artikel Penelitian}

Vol 6 No. 2, Oktober 2017

ISSN $2460-8742$

http://journal.unair.ac.id/journal-of-orthopaedic-and-traumatology-surabaya-media-104.html

\begin{tabular}{|l|l|l|r|r}
$\mathrm{T}$ & MSCS + &, 930 & 12 &, 379 \\
$\mathrm{~T}$ & $\begin{array}{l}\text { PRP } \\
\text { MSCS + }\end{array}$ &, 972 & 12 &, 928 \\
$\begin{array}{l}\text { FDBCP } \\
\text { MSCS + } \\
\text { PRP + } \\
\text { FDBCP }\end{array}$ &, 880 & 12 &, 088 \\
\hline
\end{tabular}

Dari data berikut didapatkan keempat kelompok data terdistribusi normal. Ini karena semua kelompok data memiliki nilai $\mathrm{p}>0,05$.

\section{Uji homogenitas variance}

Tabel 3. Homogenitas variance

\begin{tabular}{|l|r|r|r|}
\hline $\begin{array}{c}\text { Levene } \\
\text { Statistic }\end{array}$ & df1 & df2 & Sig. \\
\hline 1,475 & 3 & 44 &, 234 \\
\hline
\end{tabular}

Dari data diatas didapatkan bahwa variance data homogen. Ini dilihat dari nilai $p>0,05$. Karena homogenitas data normal dan homogenitas variance normal maka dapat dilakukan uji ANOVA.

\section{Uji ANOVA}

Tabel 4. Uji ANOVA

\begin{tabular}{|l|r|r|r|r|}
\hline & df & $\begin{array}{r}\text { Mean } \\
\text { square }\end{array}$ & F & Sig. \\
\hline Between Groups & 3 & 2,221 & 63,308 &, 000 \\
Within Groups & 44 &, 035 & & \\
Total & 47 & & & \\
\hline
\end{tabular}

Pada uji ANOVA didapatkan $\mathrm{p}<0,05$. Ini artinya bahwa terdapat beberapa kelompok data yang berbeda secara signifikan. Untuk melihat kelompok yang berbeda itu maka dilakukan multiple comparison.
Tabel 5. Multiple comparisons

\begin{tabular}{|l|l|c|c|c|}
\hline \multirow{4}{*}{ Perlakuan } & \multirow{3}{*}{ Perlakuan } & \multirow{2}{*}{ Sig. } & \multicolumn{2}{|c|}{$\begin{array}{c}\text { 95\% Confidence } \\
\text { Interval }\end{array}$} \\
\cline { 3 - 5 } & & & $\begin{array}{l}\text { Lower } \\
\text { Bound }\end{array}$ & $\begin{array}{l}\text { Upper } \\
\text { Bound }\end{array}$ \\
\hline MSCS & MSCS+PRP &, 000 &,- 61904 &,- 31080 \\
\cline { 2 - 5 } & $\begin{array}{l}\text { MSCS+FDBC } \\
\mathrm{P}\end{array}$ &, 642 &,- 11829 &, 18995 \\
\cline { 2 - 5 } & $\begin{array}{l}\text { MSCS+PRP } \\
\text { + FDBCP }\end{array}$ &, 000 & $-1,02679$ &,- 71855 \\
\hline
\end{tabular}

${ }^{*}$ The mean difference is significant at the 0.05 level

Dari uji multiple comparison didapatkan bahwa terdapat perbedaan signifikan antara kelompok kontrol dengan kelompok MSCS+PRP dan kelompok MSCS+FDBCP+PRP. Ini artinya bahwa kenaikan kadar MTT setelah ditambah PRP meningkat secara signifikan. Demikian juga setelah ditambah PRP+FDBCP terjadi kenaikan signifikan. Sedangkan kadar MTT setelah ditambah FDBCP menurun tetapi tidak signifikan.

\section{PEMBAHASAN}

Persentase viabilitas mesenchymal stem cells setelah dilakukan pemberian scaffold bubuk tulang rawan sapi dan platelet rich plasma dihitung dengan menggunakan MTT assay yaitu dengan menilai densitas optik. Sebagai pembanding juga dilakukan uji viabilitas dengan metoda yang sama terhadap bubuk tulang rawan sapi saja dan juga terhadap platelet rich plasma saja. Kadar MTT menunjukkan keaktifan sel. Makin tinggi MTT berarti 
jumlah sel meningkat. Demikian juga sebaliknya, makin rendah berarti jumlah sel menurun.

Penelitian ini merupakan penelitian eksprimental laboratoris menggunakan rancangan penelitian Post Test-Only Control Group Design pada kultur mesenchymal stem cells. Sampel mesenchymal stem cells formula 1 (kontrol), sampel mesenchymal stem cells formula 2 (dengan PRP), sampel mesenchymal stem cells formula 3 (dengan FDBCP) dan sampel mesenchymal stem cells formula 4 (dengan FDBCP dan PRP ) ditanamkan pada kultur dan kemudian diinkubasikan selama 24 jam. Pengukuran persentase jumlah sel yang viabel didalam kultur menggunakan metode MTT assay.

Data hasil penelitian eksperimental mengenai uji sitotoksiksitas secara in vitro pada sampel mesenchymal stem cells didapatkan secara kuantitatif yaitu dengan melihat persentase jumlah sel yang yang viabel dalam kultur. Pemeriksaan kuantitatif MTT assay berdasar pada kemampuan sel hidup untuk mereduksi garam MTT yang berwarna kuning dan larut menjadi formazan garam tetrazolium yang berwarna biru-ungu dan tidak larut. Produksi formazan dapat dihitung dengan melarutkan dan mengukur densitas optik larutan yang dihasilkan. Reaksi warna biru keunguan digunakan sebagai ukuran jumlah sel hidup. Semakin pekat warna biru ungunya semakin tinggi nilai absorpsinya hal ini menunjukkan semakin banyak jumlah sel yang hidup. Sedangkan jumlah sel dapat diukur sebagai hasil produk MTT dengan spektrofotometer pada panjang gelombang $630 \mathrm{~nm}$ sehingga semakin tinggi persentase densitas optik menunjukkan sel memiliki metabolisme aktif yang dapat mereduksi MTT yang semakin baik.

Data tentang densitas optik yang menggambarkan viabilitas mesenchymal stem cells dengan menggunakan metode MTT Assay dapat dilihat pada grafik di bawah ini.

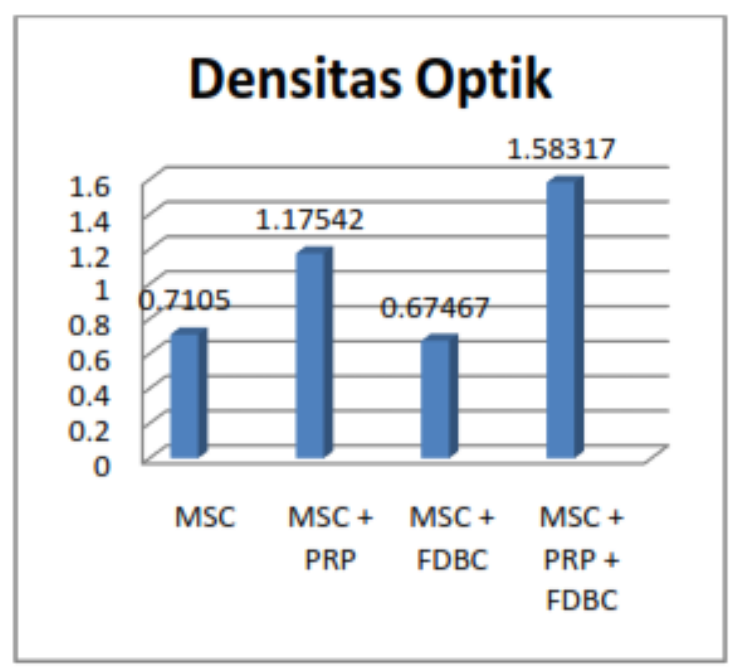

Gambar 2. Hasil pengukuran densitas optik yang menggambarkan viabilitas mesenchymal stem cells

Dari data deskriptif diatas didapatkan bahwa kadar rata-rata MTT meningkat pada kelompok yang diberi PRP yaitu 1,17542 dan kelompok yang mendapat PRP+FDBCP sebesar 1,58317. 
Sedangkan pada kelompok yang mendapat FDBCP terjadi penurunan kadar rata-rata MTTdengan rerata 0,67467. Dari data-data tersebut kita dapat menghitung viabilitas dari stem cell, yang hasilnya dapat dilihat pada grafik di bawah ini.

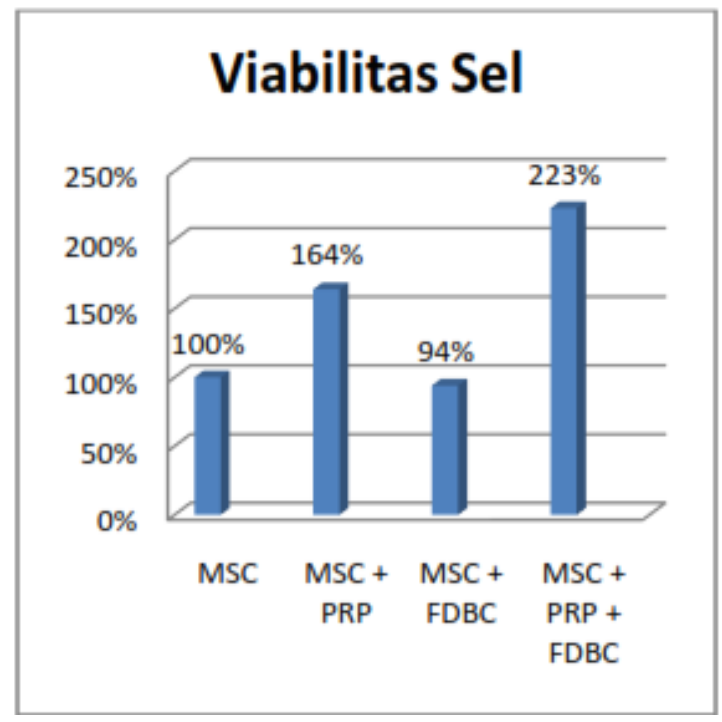

Gambar 3. Grafik persentase viabilitas mesenchymal stem cells

Dari grafik di atas dapat kita lihat bahwa viabilitas dari mesenchymal stem cells cells formula 1 (kontrol) yang kita anggap mempunyai viabilitas $100 \%$, sampel mesenchymal stem cells formula 2 (dengan PRP) meningkat sampai 164\%, sampel mesenchymal stem cells formula 3 (dengan FDBCP) didapatkan penurunan persentase yang tidak signifikan yaitu sebesar 6\%, sehingga menjadi 94\%, dan sampel mesenchymal stem cells formula 4 (dengan FDBCP dan PRP) meningkat lebih dari dua kali lipat sebesar $223 \%$.

Didapatkan bahwa formula 1 dan formula 3 menunjukkan nilai yang lebih besar daripada kelompok kontrol (100\%). Formula 3 menunjukkan hasil yang paling signifikan. Hal ini menunjukkan terjadi percepatan pertumbuhan mesenchymal stem cells pada media kultur setelah diberikan kedua jenis komponen tersebut, yaitu PRP dan FDBCP.

Hal ini membuktikan bahwa PRP dan gel larutan PRP tidak bersifat toksik, justru bersifat merangsang pertumbuhan sel, dan berdasarkan uji statistik didapatkan hasil yang signifikan $(\mathrm{p}<0.05)$. Hasil ini sesuai dengan studi yang dilakukan oleh $\mathrm{K}$. Hyunchul seperti yang membuktikan bahwa PRP meningkatkan kapasitas proliferasi dan diferensiasi pada sel tendon. ${ }^{6}$ Penelitian serupa dilakukan oleh K. Akeda yang melakukan percobaan dengan nemberikan PRP pada cartilage babi, dan membuktikan bahwa growth factor yang ada di PRP merangsang proliferasi kondrosit dan biosintesa matriks. $^{7}$

\section{KESIMPULAN DAN SARAN}

\section{Kesimpulan}

1) Secara in vitro, Platelet Rich Plasma $(P R P)$ terbukti tidak toksik terhadap pertumbuhan kultur Mesenchymal Stem Cells (MSCs).

2) Secara in vitro, Freeze Dried Bovine Cartilage Powder (FDBCPP) terbukti tidak toksik terhadap pertumbuhan 
kultur Mesenchymal stem cells (MSCs).

3) Scaffold dari bahan Platelet Rich Plasma (PRP) dan Freeze Dried Bovine Cartilage Powder (FDBCPP) tidak bersifat toksik terhadap Mesenchymal stem cells (MSCs).

4) Scaffold Scaffold dari bahan Platelet Rich Plasma (PRP) dan Freeze Dried Bovine Cartilage Powder (FDBCPP) merangsang proliferasi Mesenchymal stem cells (MSCs)

\section{Saran}

1) Untuk mendapatkan hasil yang lebih reliable perlu dilakukan penelitian in vivo (pada hewan coba).

2) Perlu kiranya untuk melakukan penelitian mengenai efek genotoksisitas dan karsinogenisitas.

\section{DAFTAR PUSTAKA}

1. Gobbi A. and Bathan L. 2009. Biological Approach for Cartilage Repair. Journal Knee Surgery, 22:3644.

2. Caplan AI. 2000. Hyaluronan-based polymers in the treatment of osteochondral defects. J Orthop Res, 18:773.

3. Getgood et al. 2009. Articular Cartilage Tissue Engineering: Today's research, tomorrow practice? $J$ Bone and Joint Surgery, 91(5) p: 565-576.

4. Simon Ziv, Philip A, Watson Biomimetic dental implants-new ways to enhance osseointegration. $J$ Can Dent Assoc. 2002;68(5):286-288.

5. Chen G, Sato T, Ushida T, Hirochika R, Shirasaki Y, Ochiai N, Tateishi T.
The use of a novel PLGA fiber/collagen composite web as a scaffold for engineering of articular cartilage tissue with adjustable thickness. J Biomed Mater Res A. 2003;67:1170-1180.

6. Jo CH, Shin JS, Lee YG, Shin WH, Kim H, Lee SY, Yoon KS, and Shin S. 2013. Platelet rich plasma for arthroscopic repair of large to massive rotator cuff tears: a randomized, single-blind, parallel-group trial. American Journal of Sports Medicine. Vol 41(10):2240-8.

7. Akeda K, An HS, Pichika R, Attawia M, Thonar EJ, Lenz ME, Uchida A, and Masuda K. 2006. Platelet-rich plasma (PRP) stimulates the extracellular matrix metabolism of porcine nucleus pulposus and anulus fibrosus cells cultured in alginate beads. Spine Volume 31 (9):959-66.

8. Williams RJ. 2006. Articular cartilage repair: Clinical approach and decision making in: operative techniques in orthopaedics. New York. Elsevier Inc, p: 218-226.

9. Gregory CA and Prockop DJ. 2007. Fundamental of culture and characterization of Mesenchymal Stem/Progenitor Cells (MSCs) from bone marrow stroma, in culture of specialized cells culture of human stem cells (edited by Freshney RI, Stacey GN, Auerbach JM). Jhon Wiley \& Sons. New jersey: 207-232.

10. Muschler GE, Nakamoto $C$, and Griffith LG. 2004. Engineering Principles of Clinical Cell-Based Tissue Engineering. J. Bone Joint Surg; Vol.86-A(7): 1542-1558. 